\title{
HUBUNGAN INTENSI PROSOSIAL DENGAN KEPUASAN KERJA PUSTAKAWAN UNIVERSITAS GADJAH MADA \\ (The Correlation between the Pro-social Intention and the Job Satisfaction of Gadjah Mada University Librarians)
}

\author{
Singgih Widodo*, Mudiyono ${ }^{* *}$, Isbandiyah ${ }^{* *}$
}

\begin{abstract}
The study is aimed at investigating the correlation between the pro-social intention and the job satisfaction of Gudjah Mada University Librarians. The subjects of the study are 70 librarians of Gadjah Mada University. The data is collected using Pro-social Intention Scale, Job Satisfaction Scale and questionnaire. An interview is also conducted with some of the subjects and users to gain a deeper understanding of quantitative analysis results.

The first hypothesis of the study suggests that the pro-social intention is positively correlated to the job satisfaction. The higher is the pro-social intention, the higher the job satisfaction is. The results of Pearson product moment correlation analysis indicate that the correlation coefficient between the pro-social intention and the job satisfaction is $r=0,481, p<0,01$. It means that there is a significant correlation between the pro-social intention and the job satisfaction. The second hypothesis suggests that controlling the factors of age and position, the pro-social intention remains positively correlated to the job satisfaction. It is tested using partial correlation analysis. The results of the analysis is $r=0,437, p<0,01$. It means that there remains to be a correlation between the prosocial intention and the job satisfaction by controlling the factors of age and position. However, they are indicative of the decrease in the correlation value. It means that the correlation of the age and position and the pro-social intention is not significantly correlated to the job satisfaction. It is found out in the study that the magnitude of the contribution of the pro-social intention to the job satisfaction is $23,2 \%$. It means that the pro-social intention variant is able to explain approximately $23,2 \%$ of the job satisfaction variant.

The coefficient of the pro-social determinution and the job satisfaction by controlling the factors of age and position is $19 \%$. It means that controlling the factors of age and position the pro-social intention variant is able to explain approximately $19 \%$ of the job satisfaction variant. Thus, it is found that the correlation between the pro-social intention and the job satisfaction decreases $4,2 \%$ when the control factors of age and position are included. Given the contribution of the pro-social intention of $23,2 \%$ to the job satisfaction, it means that $76,8 \%$ results from other factors that are not included in the study.
\end{abstract}

Key words : Prosocial Intention, Job Satisfaction, Librarian

\section{ABSTRAK}

Penelitian ini bertujuan untuk mengetahui hubungan antara intensi prososial dengan kepuasan kerja Pustakauan Universitas Gadjah Mada. Subjek penelitian berjumluh 70 pustakawan di lingkungan Universitas Gadjah Mada. Pengumpulan data dilakukan dengan menggunakan Skala Intensi Prososial, Skala Kepuasan Kerja, serta angket data subjek. Untuk memperkaya pemahaman terhadap hasil analisis kuantitatif, maka dilakukan wawancara dengan beberapa subjek dan pengguna.

Hipotesis pertama dalam penelitian ini menyatukan bahwa intensi prososial berhubungan positif dengan kepuasan kerja. Semakin tinggi intensi prososial, akan semakin tinggi pula kepuasan kerja. Berdasarkan analisis korelusi product moment dari Pearson, diperoleh hasil yang menunjukkan bahwa besarnya koefisien korelasi antara intensi prososial dengan kepuasan kerja adalah $r=0,481, p<0,01$, yang berarti ada hubungan yang signifikan antara intensi prososial dengan kepuasan kerja. Hipotesis kedua menyutakan bahwa dengan mengontrol faktor usia dan posisi jabatan, intensi prososiul tetap berhubungan positif dengan kepuasan kerja. Hipotesis ini diuji dengan menggunakan analisis korelasi parsial. Hasil analisis menunjukkan $r=0,437$, $p<0,01$, yang berarti tetap ada hubungan antara intensi prososial dengan kepuasan kerja dengan mengontrol faktor usia dan posisi jabatan, namun hasil analisis menampakkan adanya penurunan nilai korelasi. Hal tersebut dapat diartikan bahwa korelasi usia dan posisi jabatan terhudap hubungan intensi prososial dengan kepuasan kerja tidak signifikan. Dalam penelitian ini dapat diketuhui besurnyu sumbangan intensi prososial terhadap kepuasan kerja, yaitu $23,2 \%$. Hal tersebut bermakna bahwa varian tingkat intensi prososial mampu menjelaskan sekitar $23,2 \%$ varian kepuasan kerja.

Koefisien determinasi intensi prososial terhadap kepuasan kerja dengan mengontrol fuktor usia dan posisi jabatun menglaasilkan angka sebesar $19 \%$. Hal tersebut bermakna balnwa dengan mengontrol faktor usia dan posisi jabatan varian tingkat intensi prososial mampu menjelaskan sekitar $19 \%$ variun kepuasan kerja. Dengan demikian dapat diketahui bahwa hubungan antara intensi prososial dengan kepuasan kerja terjadi penurunan sekitar $4,2 \%$ ketika dua fuktor kontrol usia dan posisi jabutan disertakan. Dengan diketahuinya sumbangan intensi prososial sebesar 23,2\% terhadap kepuasan kerja, berarti sebesar 76,8\% berasal dari faktor-faktor lain yang tidak turut diteliti dalum penelitian ini.

Kata kunci: Intensi Prososial, Kepuasan kerja, Pustakawan

* Pustakawan UGM

** Fakultas Ilmu Sosial dan Ilmu Pulitik Universitas Gadjah Mada 


\section{LATAR BELAKANG}

Kemajuan teknologi informasi dan komunikasi saat ini telah mengantarkan masyarakat dunia ke sebuah era yang disebut era global, atau sering disebut dengan globalisasi. Seiring dengan perubahan tersebut, terjadi pula perubahan hidup bersama dan bermasyarakat. Pemerintah telah berusaha menggalakkan program kesetiakawanan sosial, namun upaya ini belum mampu meningkatkan perilaku prososial secara optimal di tengah masyarakat (Setiono, 1994: 45-54)

Dampak lain yang saat ini juga melanda masyarakat dunia adalah adanya tuntutan mengenai norma dan nilai yang secara universal sudah diterima oleh masyarakat dunia, misalnya hak asasi manusia, demokrasi, dan sebagainya. Bangsa mana pun harus menghormati nilai dan norma yang berlaku secara universal tersebut, jika tidak ingin dikucilkan dari pergaulan masyarakat dunia. Negara Indonesia saat ini sedang memasuki era transisi menuju sebuah Indonesia baru yang pemerintahannya bebas dari korupsi.

Dalam memasuki masa transisi ini salah satu sektor yang mendapatkan perhatian khusus adalah dunia pendidikan. Ada berbagai tingkatan lembaga yang bergerak di dunia pendidikan formal, mulai dari tingkat dasar sampai perguruan tinggi. Dari berbagai tingkatan tersebut, keberadaan perguruan tinggi menduduki posisi yang cukup vital dalam menghasilkan sumber daya manusia yang berkualitas. Berbagai sumber daya yang mendukung perguruan tinggi akan sangat mempengaruhi mutu perguruan tinggi yang bersangkutan. Sebagai sebuah organisasi, dunia pendidikan tidak hanya berorientasi pada komersial namun juga sosial, baik lembaga tersebut milik pemerintah maupun swasta.

Salah satu unsur yang turut mempengaruhi mutu perguruan tinggi adalah perpustakaan. Perkembangan teknologi informasi telah membawa pengaruh yang besar terhadap pengelolaan perpustakaan. Sehubungan dengan hal itu, maka pustakawan sebagai salah satu profesi yang berkecimpung di dunia kepustakawanan, harus selalu meningkatkan kemampuan agar dalam menjalankan profesi dapat menyesuaikan dengan perkembangan zaman.

Jika dikaitkan dengan salah satu poin dalan Rencana Strategis (Renstra) Universitas Gadjah Mada 2004-2007 di bidang perpustakaan yaitu terwujudnya sistem informasi perpustakaan yang handal, efektif serta dapat memberikan mutu pelayanan yang berkelanjutan ke taraf internasional, maka hal tersebut merupakan tantangan bagi pustakawan UGM untuk dapat meningkatkan kinerja. Selanjutnya dalam Renstra tersebut juga dicanangkan bahwa ke depan, Perpustakaan UGM diharapkan menjadi perpustakaan yang representatif, dan dapat beroperasi dengan cost-effective yang didukung dengan tersedianya pustakawan yang profesional, bermutu, serta memiliki motivasi kerja yang tinggi, agar dapat memberikan pelayanan yang baik bagi pengguna. Dalam rangka mencapai tujuan pelayanan tersebut, perpustakaan harus mampu memenuhi apa yang menjadi kebutuhan pengguna.

Di dunia pendidikan pustakawan merupakan salah satu faktor yang mempunyai andil dalam membentuk citra lembaga pendidikan. Oleh karena itu untuk dapat mewujudkan citra yang positif, pustakawan perlu memiliki kepuasan kerja yang baik sehingga tugas profesinya dapat dijalankan dengan penuh semangat serta motivasi.

Tiffin dan McCormick (dalam Hari, 2001 : 4) mengatakan bahwa masalah kepuasan kerja sangat penting bagi suatu organisasi, karena setiap karyawan yang merasa puas diharapkan dapat bekerja pada tingkat full capacity dan diharapkan dapat meningkatkan produktifitas kerja. Jika dikaitkan dengan pustakawan, dapat dikatakan bahwa pustakawan yang merasa puas dengan pekerjaannya akan mampu memberikan pelayanan terbaik yang dimilikinya kepada pengguna

Miner (dalam Hari, 2001: 4) berpendapat bahwa selain mempertimbangkan aspek-aspek ekstrinsik, untuk meningkatkan kepuasan kerja, perlu pula memperhatikan aspek intrinsik. Namun demikian perlu ditegaskan pula bahwa pustakawan bukanlah seorang altruist sebagaimana "relawan" yang sanggup mengorbankan diri mereka demi keselamatan orang lain dengan imbalan surgawi. Oleh karena itu selain faktor intrinsik, kepuasan kerja pustakawan juga akan ditentukan oleh faktor-faktor eksternal seperti gaji, insentif, fasilitas kerja, maupun lingkungan kerja secara fisik.

\section{RUMUSAN MASALAH}

Berdasarkan latar belakang di atas, dapat ditentukan permasalahan yang akan dibahas dalam penelitian ini, yaitu : Apakah ada hubungan antara intensi prososial dengan kepuasan kerja Pustakawan Universitas Gadjah Mada 


\section{MANFAAT PENELITIAN}

\author{
Manfaat yang diharapkan dari penelitian ini \\ adalah :
}

\section{A. Manfaat Teoritis}

Bagi ilmu perpustakaan penelitian ini akan memberi masukan secara ilmiah khususnya tentang intensi prososial dalam hubungannya dengan kepuasan kerja pustakawan

\section{B. Manfaat Praktis}

Bagi pengelola perpustakaan, penelitian ini dapat digunakan sebagai masukan dalam mengelola sumber daya manusia khususnya tenaga pustakawan dengan memperhatikan salah satu aspek intrinsik yang dapat mempengaruhi kepuasan kerja agar pustakawan dapat meningkatkan kinerjanya.

Bagi pustakawan, penelitian ini akan menambah wawasan bahwa kepuasan di dalam bekerja tidak hanya ditentukan oleh aspek finansial atau materi semata, melainkan juga dipengaruhi oleh aspek intrinsik yang berasal dari dalam diri.

\section{TUJUAN PENELITIAN}

Tujuan dari penelitian ini adalah untuk mengetahui hubungan antara intensi prososial dengan kepuasan kerja .

\section{KERANGKA TEORI}

\section{A. Kepuasan kerja}

Riggio (2003: 214) mendefinisikan kepuasan kerja sebagai perasaan dan perilaku individu berkenaan dengan pekerjaannya. Semua aspek dari pekerjaan yang baik maupun buruk, positif maupun negatif akan berperan menciptakan perasaan kepuasan ini.

Kepuasan kerja juga merupakan perasaan seseorang terhadap pekerjaannya (Wexley dalam As'ad, 1989: 101).

Kepuasan kerja merupakan variabel yang cukup penting untuk diteliti, karena telah terbukti berpengaruh terhadap performansi kerja, tingkat mangkir karyawan, serta tingkat turn over pada perusahaan (Riggio, 2003 : 214).
Penelitian tentang hubungan kepuasan kerja terhadap kebahagiaan serta kesehatan individu, juga telah banyak dilakukan. Salah satunya adalah penelitian Sales dan House (dalam Argyle, 2001: 101) yang menemukan bahwa kepuasan kerja berkorelasi negatif dengan kemungkinan terkena serangan jantung.

Penelitian tentang kepuasan kerja dengan posisi jabatan seseorang juga telah dilakukan oleh Clark. Penelitian Clark (dalam Argyle, 2001: 95) mengungkapkan bahwa bahwa orang akan cenderung memiliki kepuasan kerja yang meningkat seiring dengan meningkatnya posisi jabatan

Berdasarkan berbagai pendapat dan pandangan di atas, didapatkan pengertian bahwa kepuasan kerja adalah sikap dan perasaan individu terhadap pekerjaan yang merupakan hasil penilaian yang bersifat subjektif.

Dalam penelitian ini aspek kepuasan kerja yang digunakan adalah yang disusun oleh Smith dkk. (dalam Argyle, 2001: 90) meliputi kepuasan terhadap pekerjaan itu sendiri (the work itself), gaji yang diterima (pay), kesempatan untuk promosi dan pengembangan karir (opportunities for promotion), supervisor (supervision), hubungan rekan kerja (relation with coworkers), serta kondisi kerja secara fisik.

\section{B. Konsep Intensi Prososial}

\section{Intensi}

Pengertian intensi (intention) berasal dari kata to intent dan diartikan sebagai usaha yang disadari untuk mencapai tujuan atau sasaran yang telah didefinisikan secara jelas (Drever, dalam Sjafrudin, 1995: 8).

Intensi adalah niat yang ada pada diri individu untuk melakukan suatu perilaku. Intensi merupakan prediktor yang terbaik untuk terjadinya perilaku, dan intensi juga merupakan fungsi dari keyakinan seseorang yang sudah pasti dan kemudian dikaitkan dengan perilakunya (Fishbein dan Ajzen 1975: 292).

Selain berhubungan dengan sikap dan perilaku, intensi juga berhubungan dengan keyakinan (belief) seseorang terhadap objek perbuatannya. Keyakinan ini juga berhubungan dengan sikap, dan pada akhirnya juga berhubungan dengan perilaku. Keyakinan menjadi dasar sikap seseorang terhadap suatu perilaku.

I Iubungan antara keyakinan, sikap, intensi dan perilaku dapat digambarkan sebagai berikut : 


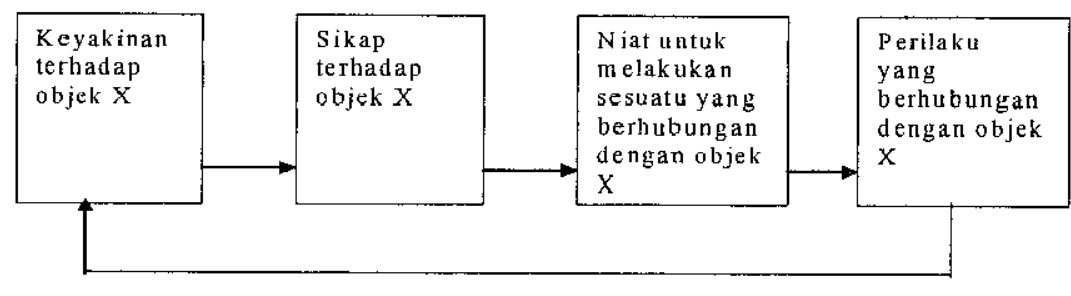

Garmbar 1

Bagan Model Hubungan antara Keyakinan, Sikap, Intensi dan Pcrilaku (s s mber : Fishbein \& Ajzen, 1975:15)

Gambar skema di atas dapat dijelaskan sebagai berikut: keyakinan atau kepercayaan terhadap objek tertentu akan mempengaruhi sikap seseorang terhadap objek tertentu. Sikap positif atau negatif tergantung dari keyakinan yang terbentuk dari banyak sedikitnya pengetahuan tentang aspek positif dan negatif dari objek tersebut. Setelah terbentuk keyakinan, maka akan menumbuhkan sikap seseorang terhadap obyek, kemudian sikap tersebut akan berhubungan dengan intensi seseorang, yang pada akhirnya akan sampai pada perilaku.

\section{Perilaku Prososial}

Baron (1997 : 356), mengemukakan bahwa perilaku prososial adalah segala bentuk tingkah laku yang bertujuan menyokong kesejahteraan orang lain, atau perilaku yang menguntungkan penerima teta pi tidak memiliki keuntungan yang jelas bagi pelakunya.

Pengertian perilaku prososial adalah perilaku yang menguntungkan orang lain yang dilakukan secara sukarela dan bukan karena paksaan. (Staub, 1979: 2).

Deaux \& Wrightsman (1984: 222) mendefinisikan perilaku prososial sebagai perilaku yang mempunyai konsekuensi positif yang ditujukan bagi kesejahteraan orang lain baik secara fisik maupun secara psikologis dan perilaku tersebut merupakan perilaku yang memberi keuntungan pada orang lain atau dirinya sendiri.

Perilaku prososial adalah tindakan-tindakan yang meliputi berbagi (sharing), kerjasama (cooperation), altruisme (altruism), suka menolong (helpfulness), menyelamatkan (rescue), dsb. (Morgan dkk., 1979:371)

Deaux \& Wrightsman (1984: 222) mengemukakan beberapa aspek perilaku prososial, antara lain menolong, berbagi, bekerjasama, bertindak jujur, menyumbang, dermawan, memperhatikan hak dan kesejahteraan orang laim, punya kepedulian terhadap orang lain.

\section{HIPOTESIS}

Berdasarkan kerangka teori di muka, penulis mengajukan 2 hipotesis yang akan diujikan dalam penelitian ini, yaitu:

1. Intensi prososial berhubungan positif dengan kepuasan kerja. Semakin tinggi intensi prososial, akan semakin tinggi pula kepuasan kerja.

2. Dengan mengontrol faktor usia dan posisi jabatan, intensi prososial tetap berhubungan positif dengan kepuasan kerja.

\section{CARA PENELITIAN}

\section{A. Metode Pengumpulan Data}

Metode pengumpulan data yang dipakai dalam penelitian ini adalah metode skala. Ada dua skala yang digunakan yaitu skala kepuasan kerja dan skala intensi prososial, yang disebarkan kepada sejumlah 73 pustakawan Universitas Gadjah Mada. Berikut penjabaran kedua skala tersebut:

\section{Skala Kepuasan Kerja}

Data kepuasan kerja dalam penelitian ini diungkap melalui skala kepuasan kerja. Skala Kepuasan Kerja disusun berdasarkan pada aspekaspek kepuasan kerja dari Smith (dalam Argyle, 2001: $90)$, yang terdiri atas kepuasan terhadap pekerjaan itu sendiri (the job itself), kepuasan terhadap gaji (pay), kesempatan promosi dan pengembangan karir (promotion), kualitas supervisor (supervision), dan hubungan dengan rekan kerja (co-workers). Untuk tujuan memperoleh tanggapan tentang kondisi kerja (secara fisik), maka ditambah satu aspek lagi pada skala kepuasan kerja, yaitu aspek kondisi kerja.

Penyekoran skala kepuasan kerja ini menggunakan metode summated rating dinana respon subjek dari tiap aitem dijumlahkan untuk mendapatkan skor total kepuasan kerja (Azwar, 2003: 105). Empat jawaban disediakan dalam setiap aitemnya, yaitu : Tidak Sesuai (TS), Kurang Sesuai (KS), Sesuai (S) dan Sangat Sesıai (SS).

\section{Skala Intensi Prososial}

Data intensi prososial pustakawan dalam penelitian iui diungkap melalui Skala Intensi Prososial (selanjutnya diberi judul Skala B), yang disusun dengan nemodifikasi skala seru pa yang disusun oleh Dantayanti (2001). 
Modifikasi skala dilakukan dengan mengubah beberapa butir dengan kalimat yang lebih sesuai pada subjek pustakawan. Sebagaimana pada skala kepuasan kerja, maka skala B ini digunakan sebagai alat ukur intensi prososial Pustakawan Universitas Gadjah Mada.

Penyusunan skala B didasarkan pada aspek-aspek perilaku prososial antara lain menolong, berbagi, bekerjasama, bertindak jujur, menyumbang, dermawan, memperhatikan hak dan kesejahteraan orang lain, serta punya kepedulian terhadap orang lain.

Setiap subjek dalam penelitian ini akan mendapatkan seperangkat skala intensi prososial dan kepada subyek diminta untuk mengisinya dengan cara memberikan tanda silang pada jawaban yang sesuai dengan pilihan dan keyakinannya. Oleh karena yang diukur adalah niat subyek dan bukan perilaku yang sebenarnya maka pengukuran dilakukan dengan menyodorkan sejumlah situasi yang merupakan stimulus bagi munculnya intensi prososial subyek.

Subjek diminta mengandaikan peristiwa tersebut terjadi pada dirinya dan setiap cerita dilengkapi dengan pengandaian tindakan subyek dalam menghadapi situasi tersebut. Pengandaian tindakan tersebut dibagi dalam tiga pilihan jawaban, kepada subjek diminta untuk memilih salah satu dari tiga pilihan yang ada pada skala intensi prososial.

\section{B. Metode Analisis Data}

Dalam penelitian ini ada dua analisis yang digunakan. Pertama adalah analisis korelasi product moment dari Pearson untuk mengetahui tingkat korelasi intensi prososial dan kepuasan kerja subjek.

Analisis korelasi parsial akan digunakan dalam penelitian ini, untuk mengetahui tingkat korelasi intensi prososial dan kepuasan kerja subjek dengan menyertakan faktor usia dan posisi jabatan sebagai variabel kontrol.

\section{HASIL PENELI'IAN}

\section{A. Hipotesis Pertama}

Hipotesis pertama menyatakan bahwa intensi prososial berhubungan positif dengan kepuasan kerja. Semakin tinggi intensi prososial, akan semakin tinggi pula kepuasan kerja. Untuk menganalisis hipotesis pertama ini digunakan korelasi product moment dari Pearson. Berdasarkan analisis, diperole $h$ hasil yang menunjukkan bahwa besarnya koefisien korelasi antara intensi prososial dengan kepuasan kerja adalah $\mathrm{r}=0,481(\mathrm{p}=<0,01)$.

Hal ini menunjukkan bahwa hipotesis pertama diterima pada taraf signifikansi $1 \%$ (one tailed). Artinya ada hubungan yang signifikan antara intensi prososial dengan kepuasan kerja.

Mulyanie (dalam Yaswardi, 1999: 78) mengemukakan bahwa besarnya koefisien korelasi yang dapat digunakan untuk keperluan prediksi adalah koefisien korelasi yang berkisar antara 0,2 sampai dengan 0,60. Dengan kata lain koefisien korelasi 0,20 sampai dengan 0,60 mempunyai nilai praktis dan teoritis dan bermanfaat untuk membuat suatu prediksi. Berdasarkan pendapat tersebut, maka koefisien korelasi sebesar 0,481 yang diperoleh dari hasil penelitian ini telah memenuhi syarat untuk prediksi.

\section{B. Hipotesis Kedua}

Hipotesis kedua berbunyi dengan mengontrol faktor usia dan posisi jabatan, intensi prososial teta $p$ berhubungan positif dengan kepuasan kerja. Hipotesis ini diuji dengan menggunakan analisis korelasi parsial.

Analisis menunjukkan $\mathrm{r}=0,437, \mathrm{p}<0,01$, (one tailed) yang berarti ada hubungan positif antara intensi prososial dengan kepuasan kerja dengan mengontrol faktor usia dan posisi jabatan. Hasil analisis tersebut menampakkan adanya penurunan nilai korelasi apabila dibandingkan ketika korelasi dianalisis tanpa mengontrol faktor usia dan posisi. Hal tersebut dapat diartikan bahwa tingkat korelasi usia dan posisi jabatan terhadap hubungan intensi prososial dengan kepuasan kerja kurang signifikan.

\section{Koefisien Determinasi}

Koefisien determinasi ditentukan dari nilai $x$ kuadrat variabel bebas intensi prososial terhadap variabel tergantung kepuasan kerja sebesar $23,2 \%$. Hal tersebut bermakna bahwa varians tingkat intensi prososial mampu menjelaskan sekitar $23,2 \%$ varians kepuasan kerja.

Koefisien determinasi intensi prososial terhadap kepuasan kerja dengan mengontrol faktor usia dan posisi sebesar $19 \%$. Hal tersebut bermakna bahwa dengan mengontrol faktor usia dan posisi jabatan varians tingkat intensi prososial mampu menjelaskan sekitar 19\% varian kepuasan kerja. 
Dengan demikian dapat diketahui bahwa hubungan antara intensi prososial dengan kepuasan kerja terjadi penurunan sekitar 4,2\% ketika dua faktor kontrol usia dan posisi jabatan disertakan.

Untuk memperjelas peran masing-masing variabel pada kepuasan kerja, peneliti melakukan analisis regresi. Hasil analisis menujukkan bahwa untuk variabel intensi prososial diperoleh Beta $=0,440$ $(t=3,945 p<0,01)$. Untuk usia, diperoleh Beta $=-0,125$ $(t=-0,743 p>0.05)$, dan posisi jabatan, besarnya Beta $=4,8(\mathrm{t}=1,628 \mathrm{p}>0,05)$

Rangkuman Uji Hipotesis

Korelasi Product Moment dari Pearson

\begin{tabular}{|l|l|l|l|}
\hline Variabel & $\mathbf{R}$ & $\mathbf{p}$ & Ket \\
\hline $\begin{array}{l}\text { Intensi Prososial dan } \\
\text { Kepuasan Kerja }\end{array}$ & 0,481 & $\begin{array}{l}0,001 \\
\text { (one tailed) }\end{array}$ & Signifikan \\
\hline
\end{tabular}

Berdasarkan hasil analisis di atas, membuktikan bahwa intensi prososial yang aspekaspeknya meliputi menolong, berbagi, menyumbang/ dermawan, kejujuran, kerjasama serta rasa peduli, dapat dijadikan sebagai salah satu aspek yang signifikan dalam menyum bang kepuasan kerja.

Baron dan Byrne (dalam Hari, 2001:58) dalam penelitiannya mengemukakan bahwa perilaku prososial yang dilakukan oleh seseorang akan membuat dirinya merasa bahagia. Pandangan tersebut didukung oleh pendapat Shaffer (dalam Schutz dan Schultz, 1994: 58) bahwa rasa bahagia yang dimiliki seseorang akan mem pengaruhi kepuasan kerjanya.

Hasil analisis tentang hubungan antara tingkat intensi prososial dengan kepuasan kerja diperoleh hasil yang signifikan $(\mathrm{r}=0,481, \mathrm{p}<0,01)$. Hal tersebut dapat diartikan bahwa tinggi rendahnya tingkat intensi prososial subjek berhubungan dengan tinggi rendahnya kepuasan kerja subjek.

Hasil analisis kedua yang menyertakan faklor usia dan posisi jabatan sebagai faktor kontrol dan diuji dengan analisis korelasi parsial, didapatkan nilai korelasi $\mathbf{r}=0,437(\mathrm{p}<0,01)$. Hasil analisis tersebut menampakkan adanya penurunan nilai korelasi apabila dibandingkan ketika korelasi dianalisis tanpa

Rangkuman Uji Hipotesis dengan Korelasi Parsial

\begin{tabular}{|l|l|l|l|}
\hline Variabel & R & p & Keterangan \\
\hline $\begin{array}{l}\text { Intensi Prososial dan Kepuasan } \\
\text { Kerja dengan mengontrol } \\
\text { Faktor usia dan posisi jabatan }\end{array}$ & 0,437 & $\begin{array}{l}0,001 \\
\text { (one tailed) }\end{array}$ & Signifikan \\
\hline
\end{tabular}

mengontrol faktor usia dan posisi jabatan. HaI ini mengindikasikan adanya pengaruh dari varia bel usia dan jabatan tersebut terhadap intensi prososial dan kepuasan kerja, namun tidak signifikan.

Hasil analisis perbandingan faktor posisi jabatan dengan tingkat kepuasan kerja subjek dapat diungkap bahwa subjek yang memiliki posisi jabatan memiliki tingkat kepuasan kerja yang lebih tinggi daripada subjek yang berstatus sebagai staf pelaksana. Hasil analisis statistik diperoleh nilai korelasi $\mathrm{r}=$ 0,020 , yang berarti signifikan. Taraf signifikansi korelasi dapat diterima apabila $p<0,05$. Hasil ini sejalan dengan penelitian Clark (dalam Argyle, 2001: 95) bahwa orang akan cenderung memiliki kepuasan kerja yang meningkat seiring dengan meningkatnya posisi jabatan.

Hubungan intensi prososial dan posisi jabatan juga dapat diungkap dalam penelitian ini yang menghasilkan nilai korelasi $\mathrm{x}=0,025(\mathrm{p}<0,05)$. Nilai tersebut bermakna bahwa semakin tinggi posisi jabatan subjek akan semakin tinggi pula intensi prososialnya.

Berdasarkan analisis data diketahui bahwa sumbangan efektif intensi prososial terhadap kepuasan kerja sebesar $23,2 \%$. Hal ini menunjukkan bahwa sebanyak $76,8 \%$ adalah faktor lain di luar intensi prososial yang mempengaruhi kepuasan kerja, yang tidak turut diteliti dalam penelitian ini. Meskipun faktor-faktor intrinsik di luar intensi prososial tersebut tidak turut diteliti secara khusus dalam penelitian ini, namun dapat diungkap dalam wawancara, adanya kecenderungan yang mengarah pada faktor-faktor penghargaan, aktualisasi diri, maupun pengembangan karir turut mempengaruhi kepuasan kerja mereka.

Rangkuman Peran Masing-masing Variabel
padaKepuasan Kerja
\begin{tabular}{|l|l|l|l|}
\hline Vaxidbe1 & Betd & $t$ & Ket \\
\hline In Lensi Prososial & 0,434 & 3,945 & Signifikan \\
\hline Usia & $-0,083$ & $-0,743$ & Tdk Signifikan \\
\hline Pusisi Jabatan & 0,189 & 1,628 & Tdk Signifikan \\
\hline
\end{tabular}

\section{KESIMPULAN}

Dari hasil analisis, dapat disinpulkan bahwa terdapat hubungan yang positif antara intensi prososial dengan kepuasan kerja. Semakin tinggi intensi prososial akan semakin tinggi pula kepuasan kerja. Demikian pula dengan mengontrol faktor usia dan posisi jabatan terdapat hubungan positif antara intensi prososial dengan kepuasan kerja. 
Hal tersebut memiliki makna bahwa intensi prososial dapat dijadikan sebagai salah satu aspek prediktor tingkat kepuasan kerja.

Sumbangan efektif intensi prososial terhadap kepuasan kerja dapat diungkap, yaitu sebesar $23,2 \%$. Hal ini menunjukkan bahwa sebanyak $76,8 \%$ adalah faktor lain di luar intensi prososial yang mempengaruhi kepuasan kerja, yang tidak turut diteliti dalam penelitian ini.

\section{DAFTAR PUSTAKA}

Anoraga, Pandji. 2001. Psikologi Kerja, Jakarta: Rineka Cipta

Apostle, Richard, 1997. Librarianship and the Information Paradigm, London: The Scarecrow Press.

Argyle, M. 2001. The Psychology of Happiness, New York: Routledge

Azwar, Saifuddin, 2003. Penyusunan Skala Psikologi, Jakarta : Pustaka Pelajar

Baron, R.A and Byrne, D. 1991, Social Psychology : understanding human interaction, Boston : Allyn Bacon.

Damayanti, Devi, 2001. Hubungan Intensi Prososial dengan Motivasi kerja Relawan Lembaga Swadaya Masyarakat di Yogyakarta, Skripsi Fakultas Psikologi Universitas Gadjah Mada

Deaux \& Wrightsman,1984. Social Psychology in the '80s, Monterey: Cole Pub.Co.

Fishbein \& Ajzen, 1975. Belief, Attitude, Intentions and Behavior: an introduction to theory and research. Menlo Park, California: Addison-Wesley Publishing Company, Inc.

Gerungan, W.A, 2002, Psikologi Sosial, Jakarta : Refika

Hadjam, M. Noor Rochman \& Nasiruddin, A. 2003. Bagaimana Mempertahankan Psychological Well Being? (pengaruh kesulitan ekonomi terhadap psychological well being dan peran kepuasan kerja serta religiusitas), Penelitian. Fakultas Psikologi, Universitas Gadjah Mada

Hadi, Sutrisno, 1989. Metotologi Research, Yogyakarta: Andi Offset

Hari, Yudil, 2001. Hubingan Intensi Prososial dengan Kepuasan Kerja pada Perawat. Skripsi, Fakultas Psikologi Universitas Gadjah Mada

Johnson, Doyle Paul. 1986. Sociological Theory. (terjemahan). Jakarta: Gramedia
Meyers, Lawrence. 1978. Behavioral Research : theory, procedure and design. San Fransisco, California: Freeman \& Company

Morgan, Cliffort T. 1979. Introduction to Psychology, New York: McGraw-Hill

Muchinsky, Paul M. 1987. Psychology Applied to Work : an Introduction to Industrial and Organizational Psychology. Chicago: The Dorey Press

Murray, Richard A., 1999. Job Satisfaction of Professional and Paraprofessional Library Staf at the University of North Carolina at Chapel Hill (master paper). www.ils.unc.edu/-murr/satisfaction/pdf.

Pendit, Putu Laxman, 2003, Penelitian Ilmu Perpustakaan dan Informasi, Jakarta : JIP-Fakultas Sastra Universitas Indonesia

Poerwanti, Endang. 2000. Pendekatan Kuantitatif dalam Penelitian Perilaku. Malang:FKIP Universitas Muhammadiyah Malang.

Riggio, Ronald, E, 2003. Introduction to Industrial Organizational Psychology. London : Scott Foresman

Saal, Frank E \& Knight, Patrick A., 1988. Industrial Organizational Psychology: science and practice. California: Boos Cole Company

Schultz \& Schultz 1994. Psychology at Work Today: an Introduction to Industrial and Organizational Psychology (6 ${ }^{\text {th }}$ edition). New York: Macmillan Publishing Company

Sears. David O. 1985. Social Psychology (terjemahan). Jakarta : Erlangga

Setiono, K. 1994. Perkembangan Penalaran Moral Tinjauan Teori Sosial-Kognitif Jurmal Pengembangan Masyarakat. No.1 hal. 45-54, Jakarta: Ikatan Sarjana Psikologi Indonesia

Sjafruddin, Djati Noer, 1995. Hubungan antara Penalaran Moral dengan Intensi Prososial, Skripsi Fakultas Psikologi, Universitas Gadjah Mada

Staub, E. 1979. Positive Social Behavior and Morality, Vol. II, New York:Academic Press.

Sulistyo-Basuki, 1993, Pengantar Ilmu Perpustakan, Jakarta : Gramedia

Yaswardi. 1999 Intensi Prososial Siswa SMLI 9 Janbi Ditinjau dari Prestasi Belajar Mata Pelajaran PPKn, Tingkat Pendidikan Orang Tua, dan Tingkat Penghasilan Orang Tua. Tesis Program Pascasarjana Universitas Gadjah Mada 